\title{
Customer Experience of CHISO: The Centuries-old Business of Japanese Luxury Kimono Garments
}

\author{
Masakazu Ishikawa ${ }^{1,2}$, Shin'ya Nagasawa ${ }^{2}$ \\ ${ }^{1}$ Graduate School of Commerce, Waseda University, Tokyo, Japan \\ ${ }^{2}$ Grace Inc., Tokyo, Japan
}

\section{Email address:}

steinbach@nifty.com (M. Ishikawa),nagasawa@waseda.jp (S. Nagasawa)

\section{To cite this article:}

Masakazu Ishikawa, Shin'ya Nagasawa. Customer Experience of CHISO: The Centuries-old Business of Japanese Luxury Kimono Garments. Science Journal of Business and Management. Special Issue: Customer Experience Management/Marketing Branding.

Vol. 3, No. 2-1, 2015, pp. 83-91. doi: 10.11648/j.sjbm.s.2015030201.22

\begin{abstract}
CHISO is a 460-year-old business based in Kyoto, Japan, that manufactures the traditional kimono. CHISO does not publicly advertise its product, but the company cooperates with high-visibility magazines to provide Yuzen kimonos for those graphic articles. CHISO also actively seeks to provide kimonos for Kyoto's traditional dance theater, movies, and television dramas. We analyzed CHISO with several marketing models, including the four Ps, SWOT, VRIO and customer experience. We presupposed that it would be more effective to use the customer experience framework espoused by Bernd $\mathrm{H}$. Schmitt rather than the traditional four Ps to analyze luxury products. CHISO has several crises during its long history, all of which were handled with aplomb.
\end{abstract}

Keywords: Customer Experience, Kimono, Yuzen, Japanese Luxury

\section{Introduction}

\subsection{Research Question and Objectives}

No company last forever. Even Pan American World Airways, once thought of the symbol of the Pax Americana, which had a fleet more than 200 jet airliners, went bankrupt in 1991, 65 years after it was founded. General Motors Corporation (GM) went into bankruptcy in 2009, 102 years after being founded, yet GM was re-listed on the New York Stock Exchange by the help of the federal government in 2010.

CHISO, Japanese manufacturer of traditional Yuzen kimono garment, has survived an astonishing 460 years.

Why CHISO could survive such a long years? This study tries to explore how CHISO could survive so many years.

\subsection{Research Method}

Our research approach was primarily the Interview with the top management of CHISO, including the Sozaemon Nishimura fifteenth; Head of CHISO, Yasuji Nakata; Executive vice president of CHISO (After the interview, he was promoted to CEO of CHISO.), and En ISomoto; CEO of Art NISHIMURA, the subsidiary company of CHISO.

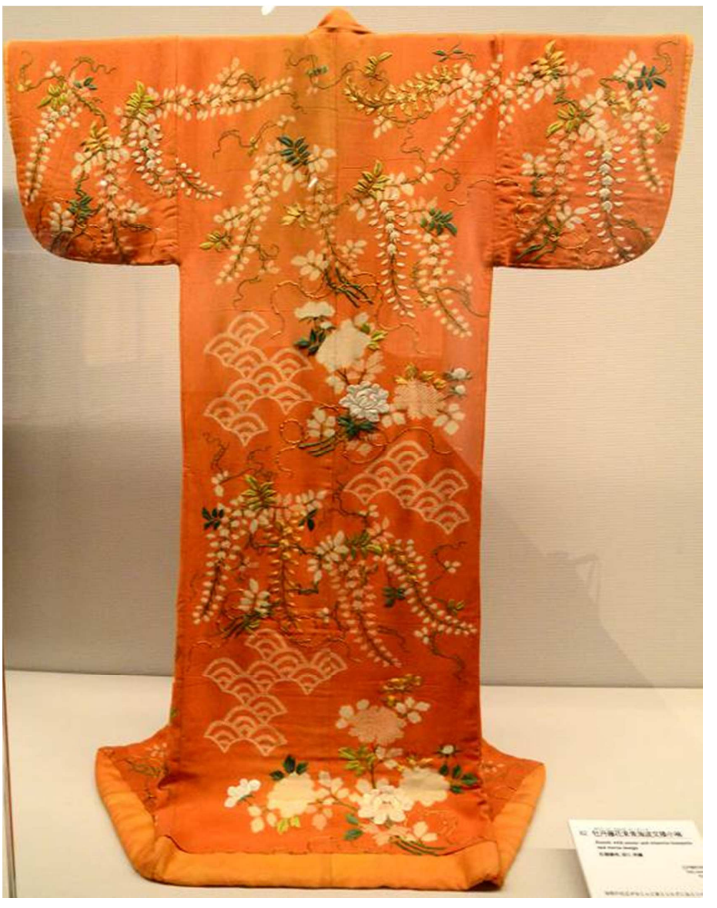

Figure 1. Yuzen Kimono of CHISO in 18th century. Shot in the Museum of Kyoto. 


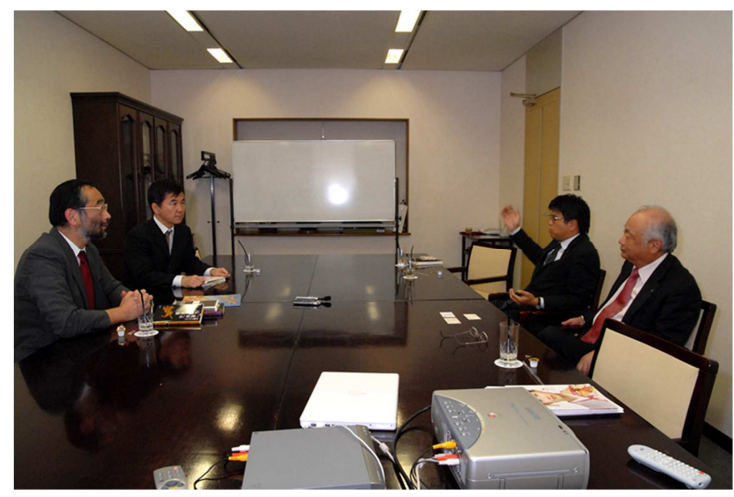

Figure 2. Interview with the top management of CHISO.

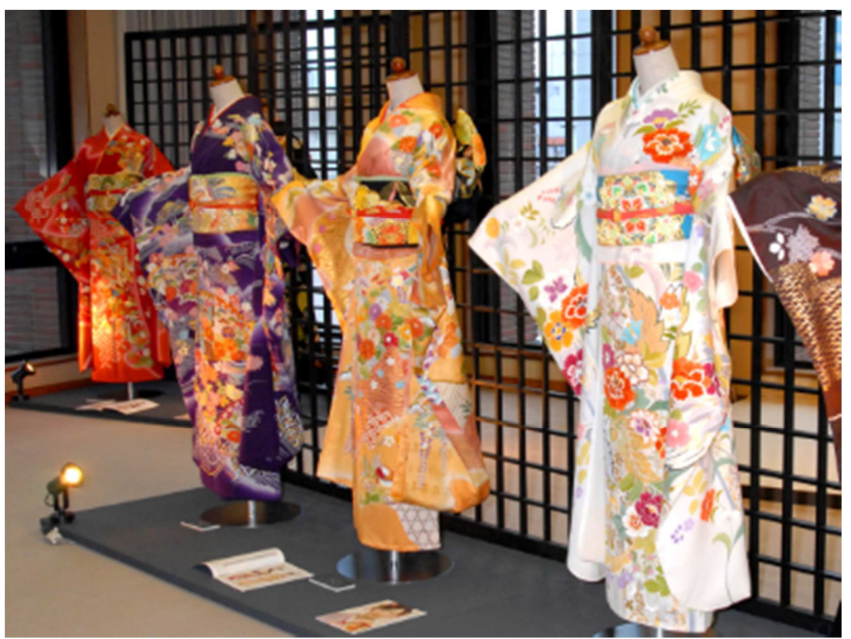

Figure 3. Exzmples of Yuzen Kimono manufactured by CHISO.

Besides the interview of top management, we deeply went into the craft center (bottega) and carried out the field reconnaissance on the manufacturing process of CHISO's Yuzen, where usually outsiders are completely prohibited from entering the manufacturing sites of CHISO. We were exceptionally permitted to enter and to watch the craft center (bottega) of CHISO.

We thirdly carried out survey at the museums including the Tokyo National Museum, and Museum of Kyoto, that own or owe the historical documentary records on CHISO and ancient Kosode-kimono related to CHISO, and we also did the bibliographical survey.

\section{Yuzen (Kyo-Yuzen): Japanese Luxury}

The kimono is a Japanese traditional garment. Kyoto has about 5,000 business establishments devoted to the manufacture or sale the kimono.

One reason why kimono industry is centered in Kyoto is the fact that the city was the ancient capital of Japan since the eighth century CE. It was controversial when capital city was moved from Kyoto to Tokyo: to this day, some historians refer to the time when the emperor transfered in Meiji era, as a "capital relocation."The emperor and aristocracy needed luxury clothing indicative of their great authority. Another reason for business accumulation in Kyoto is the fact that since 6th century, kimono clothing technicians clustered in the Yamashiro area: which overlaps present-day Kyoto.

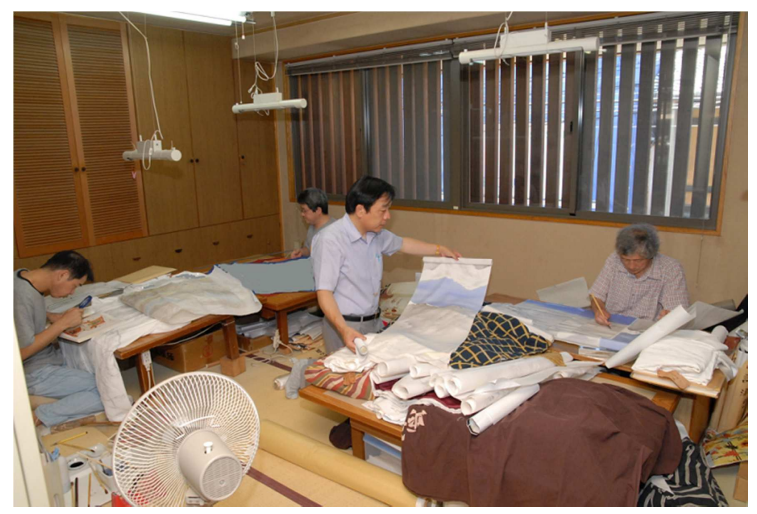

Figure 4. CHISO's allied artisans house.

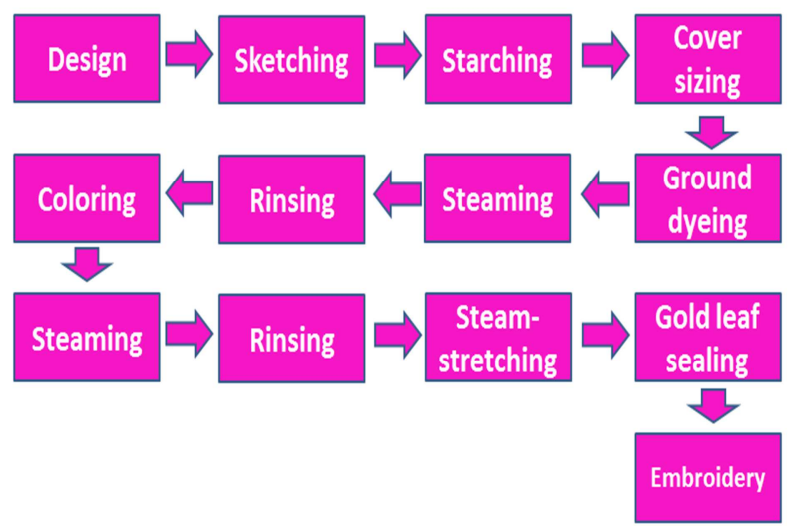

Figure 5. Manufacturing process of Yuzen kimonos.

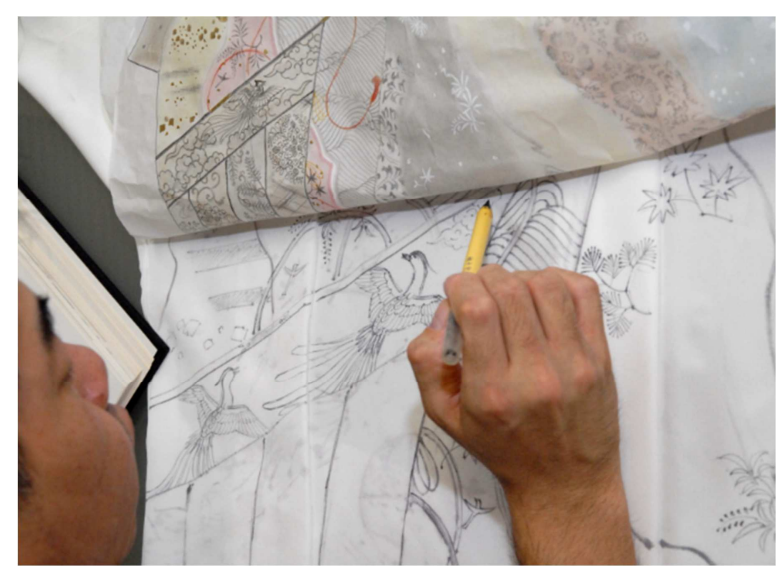

Figure 6. Sketching with vanishing ink.

Kimono garments manufactured in Kyoto fall into two major categories: (1) Nishijin-ori (thread-dyeing ahead and then weaving later), and (2) Yuzen or Kyo-Yuzen (weaving the white thread into textiles and then drawing and dyeing later). The manufacturing process of Yuzen is divided into many phases as shown in Figure 5, and each phase is highly specialized by each craftsman.

First, designers draft plans on paper, then which a sketcher outlines on white textile with vanishing vegetable ink. As starching technician then traces the lines made by the sketcher. 


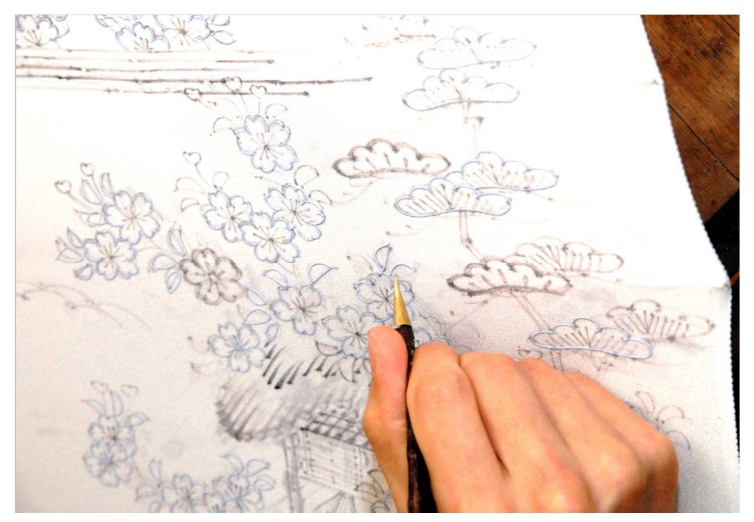

Figure 7. Starching on lines of vanishing ink.

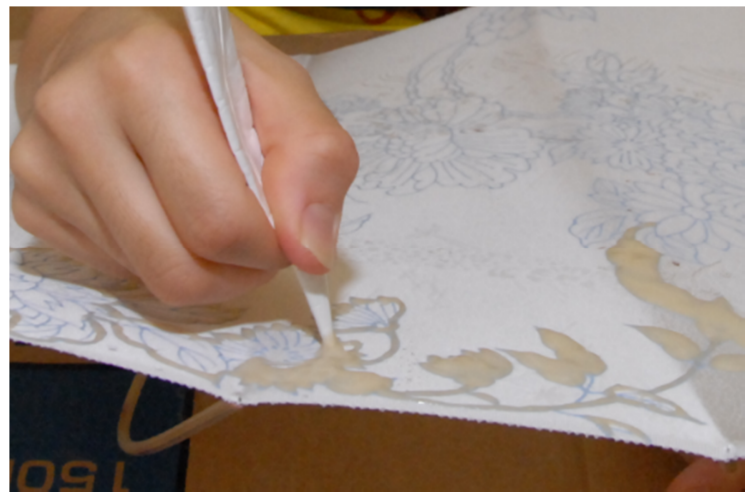

Figure 8. Cover-sizing with resisting starch.

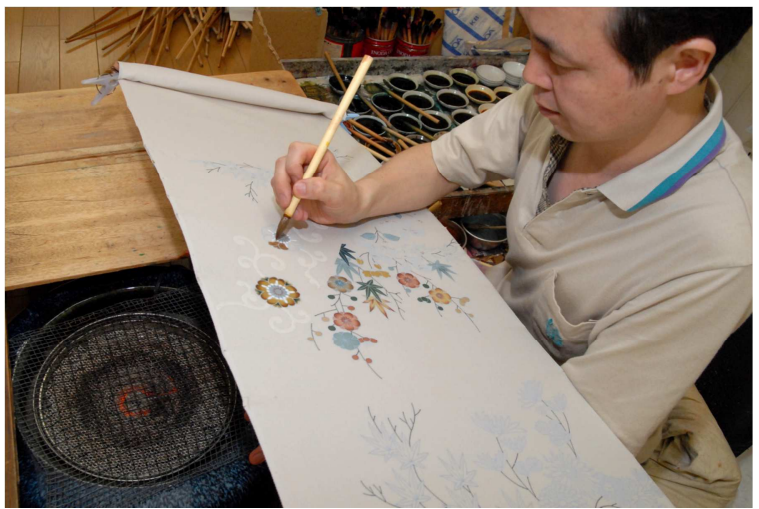

Figure 9. Coloring with brazier heating.

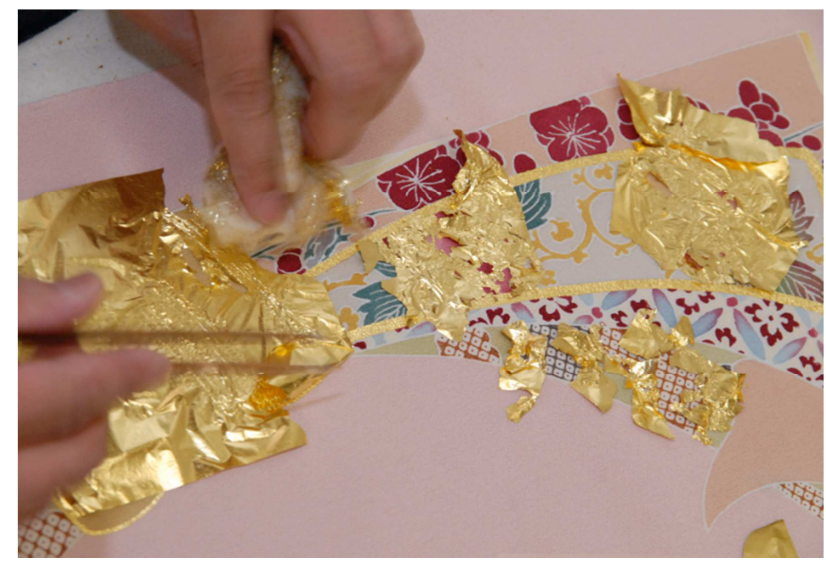

Figure 10. Gold leaf sealing on a Yuzen kimono.
A cover-sizing technician covers the textile with an agent to protect some areas from dyeing, and the material is dyed.

Afterward, as steaming technician steams the textile to affix the dye. Then, a rinsing technician rinses the textile to wash away the colors and adhesive. A coloring technician colors some parts of the design.

Steamers fix the color, and a rinsing technician rinses the garment. A steam-stretching technician stretches the textile into a flat and smooth shape so the gold leaf technician can add gold leaf, which adds luxuriousness.

Finally, the embroidery technician embroiders some of the dyed textile in order to draw attention to certain details.

\section{Analysis of CHISO Brand}

\subsection{Outline of the CHISO Brand}

The CHISO brand is not common among the rank-and-file populace, but is fairly famous among members of high society. This is a peculiar situation, given other luxury brands (e.g., Porsche, Ferrari, Hermès, Rolex) are well known across economic strata. We presume there is one reason for this reality: CHISO had not been advertising thus far.

Table 1. Profile of CHISO.

\begin{tabular}{|c|c|}
\hline Item & Description \\
\hline Business field & Yuzen manufacturing and distributing \\
\hline $\begin{array}{l}\text { Home city: } \\
\text { HQ }\end{array}$ & Sanjo-Karasuma, Kyoto, Kyoto \\
\hline Representative & 15th Nishimura Sozaemon \\
\hline $\begin{array}{l}\text { Big } \\
\text { shareholders }\end{array}$ & $\begin{array}{l}\text { Nishimura Sozaemon } \\
\text { Daimaru Matsuzakaya Department Stores Co. Ltd. } \\
\text { Takashimaya Co., Ltd. } \\
\text { Employees' stock ownership plan }\end{array}$ \\
\hline Product source & $\begin{array}{l}\text { Mikumo Orimono Textile, Murayama Shisyuten } \\
\text { Embroidery, Kimura Sensho Dyeing, Takahashi Toku } \\
\text { Dyeing / }\end{array}$ \\
\hline $\begin{array}{l}\text { Sale } \\
\text { destinations }\end{array}$ & $\begin{array}{l}\text { Matsuzakaya Department Stores Co. Ltd., } \\
\text { Hankyu Hanshin Holdings, Inc., } \\
\text { Kintetsu Department Store Co., Ltd. / }\end{array}$ \\
\hline $\begin{array}{l}\text { Operation } \\
\text { performance }\end{array}$ & $\begin{array}{l}\text { Amount of proceeds: } 3,000 \text { million JPY } \\
\text { ( } 25.42 \text { million dollars; } \$ 1=118 \mathrm{JPY})\end{array}$ \\
\hline
\end{tabular}

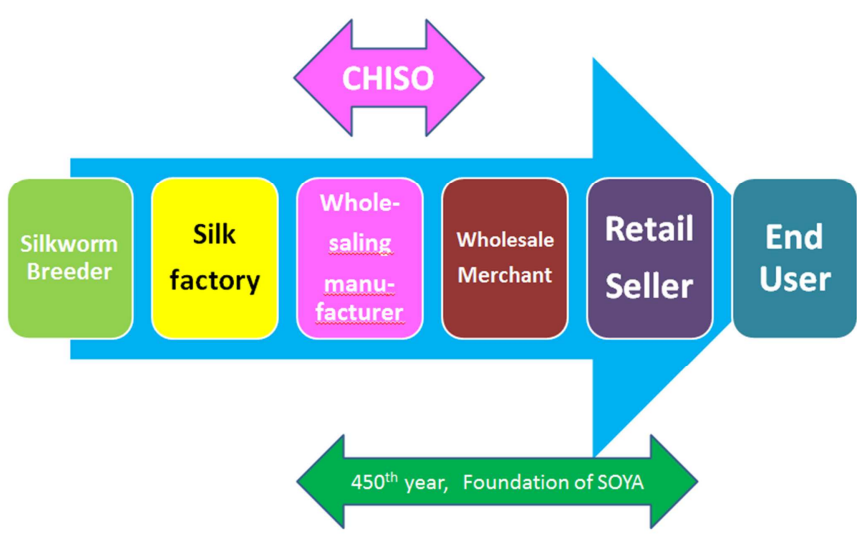

Figure 11. Value chain of Yuzen kimono. 


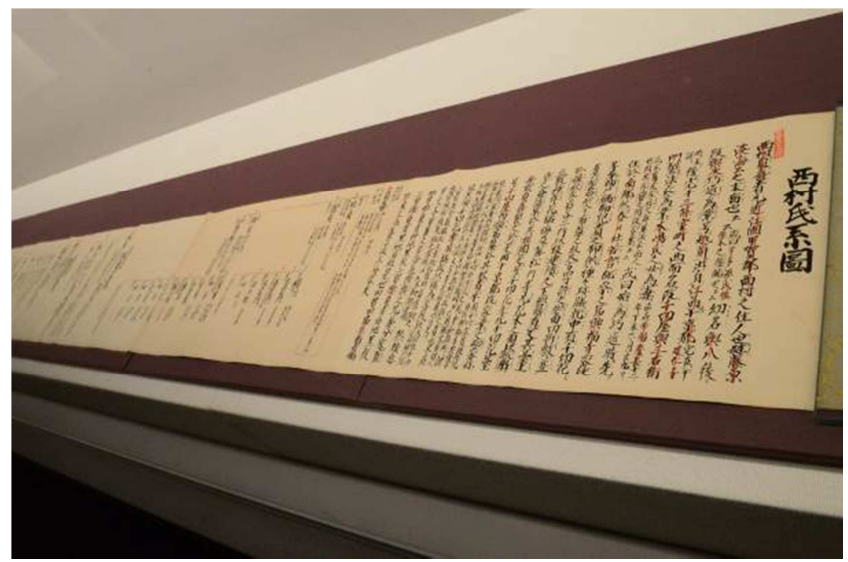

Figure 12. CHISO's family tree. The Museum of Kyoto.

However, CHISO has been cooperating to provide Yuzen kimonos for high-visibility magazine articles as well as theater, films, and television dramas. In these media presentations, models or performers wear CHISO's gorgeous Yuzen kimonos. The average person is oblivious of the origin of the garments despite ending credits, whereas aficionadas can identify CHISO's kimonos without even seeing a credit line.

\subsection{Ps analysis of CHISO}

A traditional marketing mix analysis of CHISO as shown in Table 2 would be as follows:

Table 2. 4 Ps analysis of CHISO.

\begin{tabular}{|c|c|}
\hline 4Ps & Analysis on CHISO \\
\hline Promotion & $\begin{array}{l}\text {-Kimono manufacturing on the back of } 460 \text { year history. } \\
\text {-Kyo-Yuzen that created by Mr. Miyazaki Yuzen in } 17 \text { th } \\
\text { century. } \\
\text {-Kudos among Kimono aficionadas. } \\
\text { - Spectacular colorific design with traditional picture. } \\
\text {-Limited production of a wide variety of design. } \\
\text {-Fairly expensive in comparison with other companies' } \\
\text { Kimonos. (Major price range is } 500-1,000 \text { thousand JPY. Or } \\
4.3-8.6 \text { thousand US dollars). } \\
\text { •"Tokusen"; Specially selected line's price range more than } \\
1,000 \text { thousand JPY. ( } 8.6-25 \text { thousand US dollars) } \\
\text {-CHISO had been dedicated itself to manufacturing and } \\
\text { distributing for } 450 \text { years but not retail until } 2006 \text {. } \\
\text {-Most Sales on the floor of the top-tier department stores. } \\
\text {-Almost no advertising. } \\
\text {-Cooperating to provide Yuzen Kimonos for high class } \\
\text { magazines' articles in a proactive manner. } \\
\text {-Cooperating to provide Yuzen Kimonos for Kyoto's } \\
\text { traditional dance stages or movies or TV dramas. }\end{array}$ \\
\hline
\end{tabular}

Products of CHISO, refer to the kimono manufacturing process, which dates back 460 years. (Kyo-Yuzen was created by Miyazaki Yuzen in seventeenth century.) The Yuzen kimono has a spectacular, colorful design that makes use of traditional imagery, and a limited run of each kimono is manufactured. Products are manufactured by a family business managed by Nishimura family.

Regarding price, Yuzen kimonos are fairly expensive in comparison with those produced by other manufacturers. The price range is 500 thousand to million yen $(4,300-8,600$ US dollars). "Tokusen" garments, a specially selected line, all are priced at more than a million yen. (more than 8.6 thousand US dollars.)

For place, CHISO has dedicated itself to manufacturing and distributing for 450 years, 10 years before 460 years, but not to retailing until 2006. Most sales are made in top-tier department stores.

For promotion, CHISO has not advertised, but the company has been proactive in placing its products in high-visibility magazines' articles and cooperating to provide kimonos for theater, film, and television productions.

\subsection{SWOT Analysis of CHISO}

We also analyzed CHISO with a SWOT (strength, weakness, opportunity, threat) analysis as shown in Table 3.

A strength of CHISO is its powerful brand name. Kimono aficionadas are wont to say, "When it comes to Kyo-YUZEN, it is definitely CHISO." The company's long history and enormous design data library.

Regarding weakness, CHISO had no retail presence untill the twenty-first century. The company only started retailing an affordable price line after operating for more than 450 years. However, CHISO still does not have retail shop for its line of luxury kimonos.

For opportunity, CHISO recently tried to collaborate with different types of industries and businesses, including SWAROVSKI (jewelry), KRUG (champagne), PORTER (luggage/bags), Typhoon (surfboards), AKIBO (bicycle), LOTTE (confections), BLYTHE (dolls), SUNTORY (PET-bottle tea), TBS (television drama), Triumph (women's underwear), and so on. These partnerships provided CHISO with an opportunity to diversify its products lines.

For threat, we must refer to the gradual decline in demand for kimono garments in the Japanese market. The presence of discount companies that sell mass-produced kimonos may also be a threat to CHISO, despite the differences in the target-markets.

Table 3. SWOT analysis of CHISO.

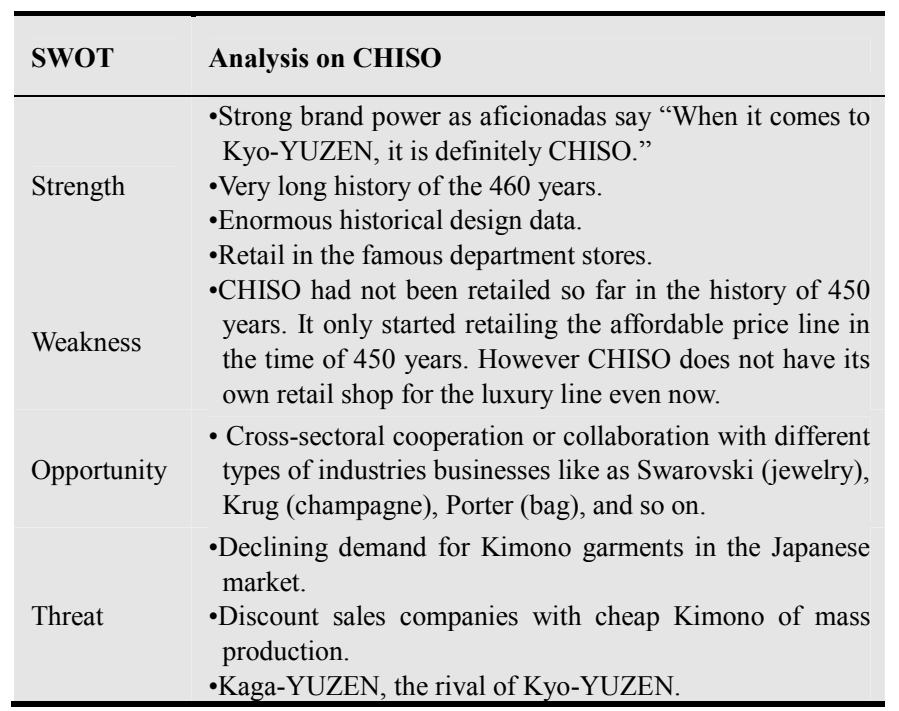




\subsection{VRIO Analysis of CHISO}

We also used the VRIO (value, rarity, inimitability, and organization) framework to analyze CHISO. This resource-based view (RBV) was proposed by Jay Barney. RBV supposes that a competitive advantage can be derived from the internal resources and capabilities of a company.

In the VRIO framework, value refers to CHISO's enormous data-base of classical designs, which covers the near entirety of Japanese culture. Rarity refers to the luxury status of Yuzen kimonos, which are very rare even on the Japanese market.

For inimitability, it is very difficult to imitate the high-level artisan skills that contribute to each garment, and it is impossible to duplicate hundreds of years of experience or imitate the trust of the Purveyor to the Royal Household. Regarding organization, we can characterize CHISO as a design-centered organization.

\section{Table 4. VRIO analysis of CHISO.}

\begin{tabular}{|c|c|}
\hline Resources & Analysis on CHISO \\
\hline Value & $\begin{array}{l}\text { - One of the most important value bears a core part of } \\
\text { Japanese culture. }\end{array}$ \\
\hline Rarity & $\begin{array}{l}\text {-Luxury YUZEN Kimonos are very rare even in Japanese } \\
\text { market. }\end{array}$ \\
\hline Inimitability & $\begin{array}{l}\text {-Very difficult to imitate the high level artisans' skills. } \\
\text {-Impossible to imitate the history of } 460 \text { years. } \\
\text {-Very difficult to imitate the trust and reliance of the } \\
\text { Purveyor to the Royal Household. } \\
\text {-But sometimes easy to imitate to its designs itself. }\end{array}$ \\
\hline Organization & $\begin{array}{l}\text { - Designing centered organization. } \\
\text { - Centuries long of generation to generation relationship } \\
\text { with the first grade artisans. }\end{array}$ \\
\hline
\end{tabular}

\section{Strategic Experiential Modules (SEMs) of CHISO}

We also used Strategic Experiential Modules (SEMs) to analyze CHISO. We felt that it would be more appropriate to analyze luxury products with the framework of customer experience, which is propounded by Bernd $\mathrm{H}$. Schmitt, rather than the traditional four Ps.

According to Schmitt, SEMs consist of five modules: SENSE, FEEL, THINK, ACT, and RELATE.

Table 5. Customer experience of Rouge Allure.

\begin{tabular}{|c|c|}
\hline Module & Descriptions of customer experience of CHISO \\
\hline SENSE & - Spectacular colorific design with traditional picture motif. \\
\hline FEEL & $\begin{array}{l}\text { Uplifting feeling that one can wears CHISO's luxury Yuzen } \\
\text { Kimono: the stylishness of authentic Kyoto culture. }\end{array}$ \\
\hline THINK & $\begin{array}{l}\text { Amazement and the acclaim to the fact of } 460 \text { years history } \\
\text { of CHISO. } \\
\text { Wonderment for the complicated manufacturing process of } \\
\text { Yuzen Kimono and acclaim for those artisan skill. }\end{array}$ \\
\hline ACT & $\begin{array}{l}\text { Action of going to the now-defunct site of ancient palace; } \\
\text { "Sanjo-Karasuma-Gosyo"where now there is the } \\
\text { headquarter of CHISO. } \\
\text { Action of going to the gallery of Yuzen Kimono in CHISO } \\
\text { HQ. }\end{array}$ \\
\hline RELATE & $\begin{array}{l}\text { Interaction with top-tier people who loves Japanese-style } \\
\text { clothing or CHISO brand. }\end{array}$ \\
\hline
\end{tabular}

\subsection{SENSE}

According to Schmitt (1999), "SENSE marketing appeals to the senses with the objective of creating sensory experiences through sight, sound, touch, taste, and smell." For SENSE, we can refer to the colorful design and traditional picture motifs of CHISO's products. People of Kyoto refer to "Han-nari": the dialect of Kyoto that means bright floridness. CHISO's Yuzen kimono exemplifies the world of "Han-nari" of Kyoto.

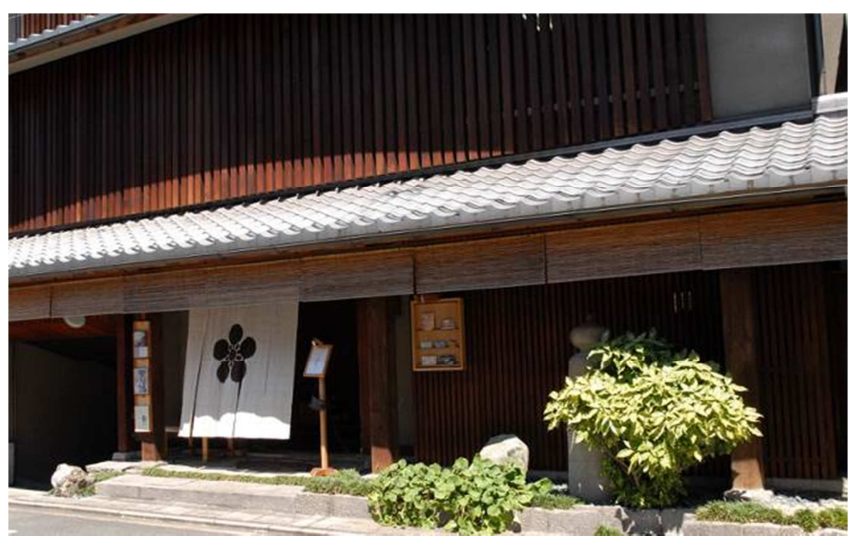

Figure 13. CHISO's allied artisans house.

\subsection{FEEL}

Schmitt said, "FEEL marketing appeals to customers' inner feelings and emotions, with the objective of creating affective experiences that range from mildly positive moods linked to a brand to strong emotions of joy and pride." CHISO's FEEL marketing refers to the uplifting feeling one gets from wearing a luxury garment that embodies the style of authentic Kyoto culture.

Figure 14 shows a typical Japanese traditional motif: "Treasure ship" that symbolizes wealth and fortune. All of CHISO's traditional motifs are auspicious without exception, so the owners of Yuzen often report a sense of wuphoria or pride when wearing one of the company's kimonos.

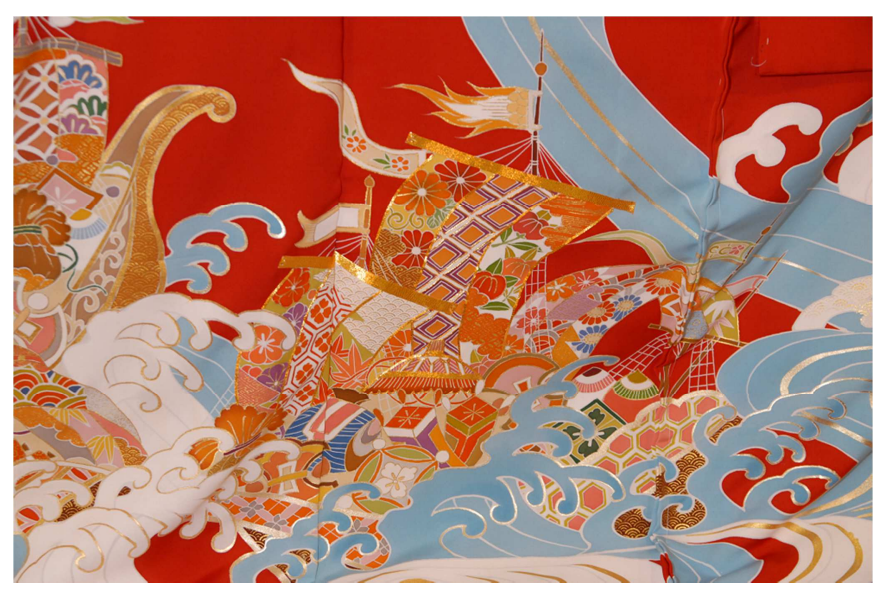

Figure 14. Traditional motif of "treasure ship." 


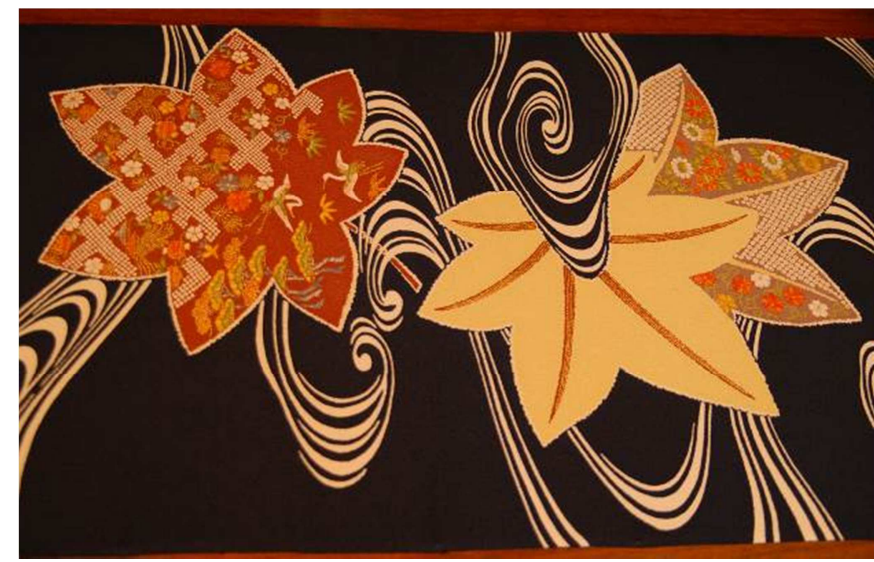

Figure 15. Fusion of classic and modern; design of autumn leaves on the river:

\subsection{THINK}

Continuing with Schmitt's framework: "THINK marketing appeals to the intellect with the objective of creating cognitive, problem-solving experiences that engage customers' convergent and divergent thinking through surprise, intrigue, and provocation." CHISO's THINK marketing, we refers to that the amazement and acclaim associated with the company's 460-year history as well as wonderment at the complicated manufacturing process and skills of the artisans. And we can also refer to the long succession of fifteenth generation of a name: "Sozaemon NISHIMURA," only the name of a head of the family business, handed down from generation to generation.

\section{4. $A C T$}

ACT marketing aims to affect bodily experiences, lifestyles, and interactions," Schmitt said. For ACT marketing, we can state there is value in the action of visiting the now-defunct site of an ancient noble palace, "Sanjo-Karasuma-Gosyo," which is the current headquarters of CHISO. The company's kimono gallery, on the second floor of its headquarters, houses about 2,000 kimono garments and historical drawings.

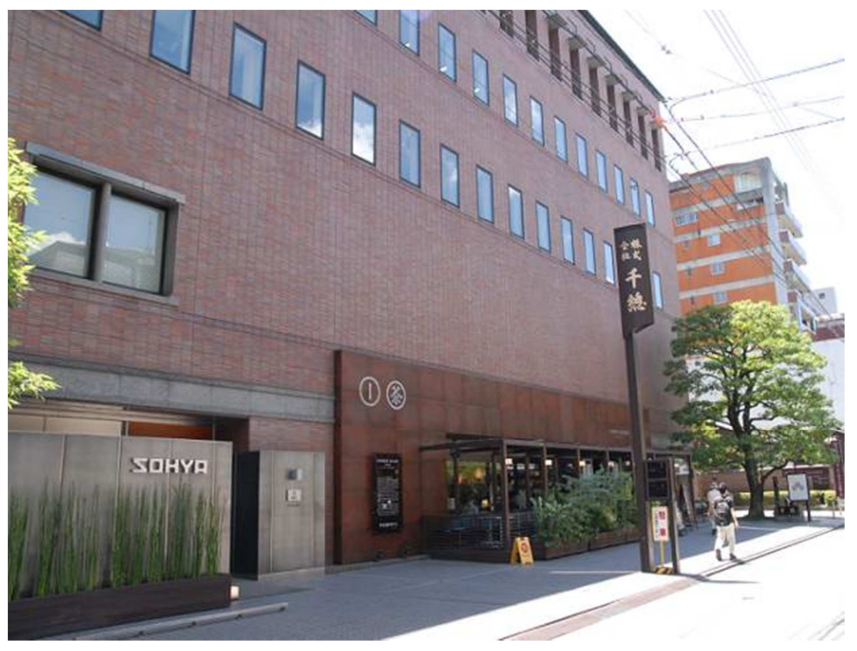

Figure 16. CHISO's headquarter.

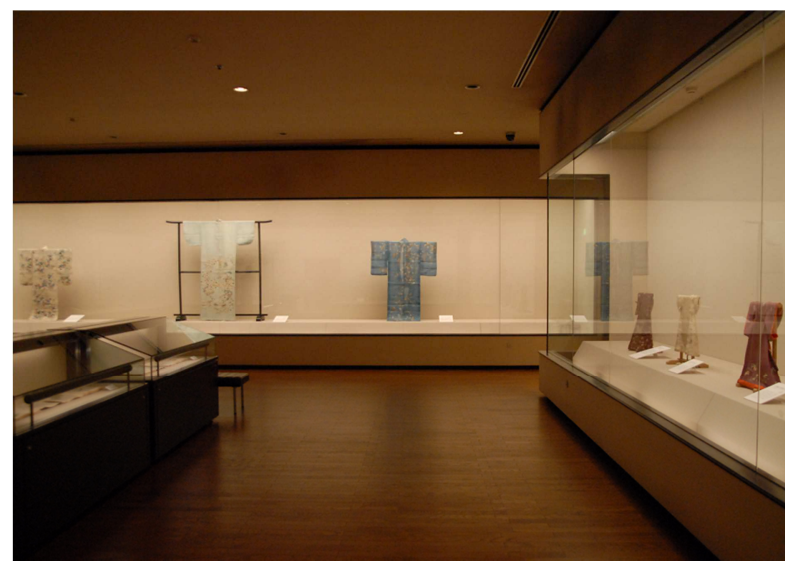

Figure 17. CHISO gallery.

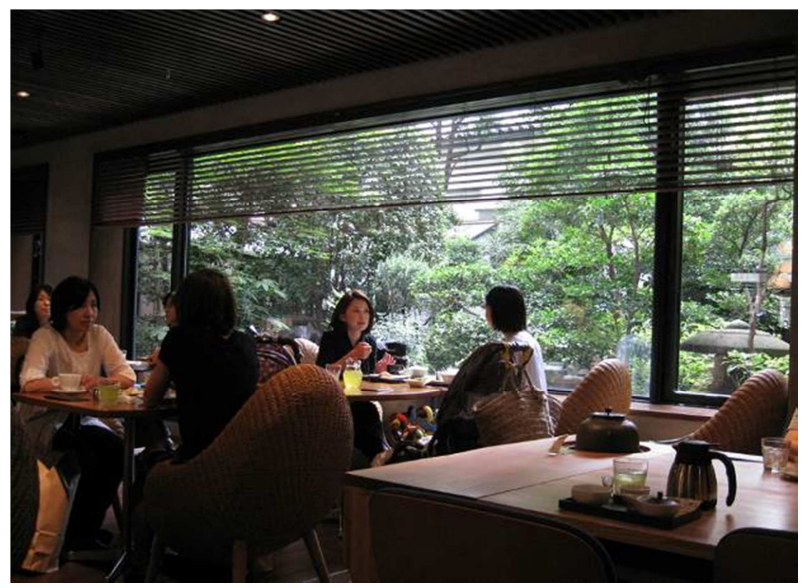

Figure 18. IYEMON SALON KYOTO.

There is also the action of going to a Japanese-inspired café, IYEMON SALON KYOTO on the first floor of CHISO's headquarters. IYEMON SALON KYOTO is managed by CAFÉ COMPANY under the licence of Suntory Holdings Limited: one of the biggest Japanese brewing and distilling companies. IYEMON SALON KYOTO is a typicaly a café-style shop, but is distinct from Western cafés such as STARBUCKS in that it embraces and sells Japanese green tea culture as well as coffee. IYEMON SALON KYOTO is located beside a beautiful Japanese garden which people can visit as they drink their tea or coffee.

\subsection{RELATE}

"RELATE marketing expands beyond the individual's personal, private feelings, thus adding to 'individual experiences' and relating the individual to his or her ideal self, other people, or cultures," Schmitt said. Regarding RELATE marketing, we can point to the interaction with dynamic people who love Japanese-style clothing or the CHISO brand.

\section{Company Crises}

CHISO has experienced several crises during its 460 years of operation. It is often said that there is one great crisis each century not only for companies, but also for society. CHISO experienced crises in this manner. 
CHISO operates as a family business, and the ancestors of CHISO family worked as the carpenters specializing in temples or shrines.

Then sixteenth century, it was an age of provincial wars in Japan, which was the first crisis the company endured. This was a hardest time for specialized carpenters because eachprovinces was focused on war expenditures and tended to shun repairing temples or shrines. Moreover, temples and shrines sometimes became military targets for destruction. Thus, ancestors of CHISO family changed careers to focus on making garments. However, the clothing CHISO initially produced was not elaborate garments for women, but rather clerical garments assciated with war time.

The second crisis faced by the company was sumptuary legislation promulgated by the Tokugawa feudal government in the seventeenth century. This time known as the Little Ice Age in Europe. Japan faced a similar situation, to the point that there was some famine in the northeastern archipelago. The economic system of Feudal Japan relied on rice as currency, but due to the famines, the gross national product fell so much that the government had to promulgate sumptuary law. That legislation prohibited gold brocade or deluxe embroidery on garments. During that time, the company tried to take advantage of loopholes in the laws in order to continue manufacturing their products. Eventually, CHISO invented the Yuzen dyeing process, which allows for aluxurious garment without gold brocade or deluxe embroidery.

The third crisis for CHISO occured in 1868, when the Meiji government took the reins from the Tokugawa shogunate regime. The new government introduced a Europeanization policy that promoted Western clothes and de-emphasized Asian culture such as the Japanese traditional kimono. This presented tremendous change for CHISO. Soon thereafter, CHISO began to innovate the art of dyeing for exporting products to Europe.

The company also invented a manufacturing method for Yuzen dyeing with patterns that used paper patterns for massproduction. Yuzen dyeing with patterns could not satisfy aficionados at the highest echelon of society, but the newly invented production method was able to reduce production costs and allowed for the development of much cheaper lines for the average consumer.

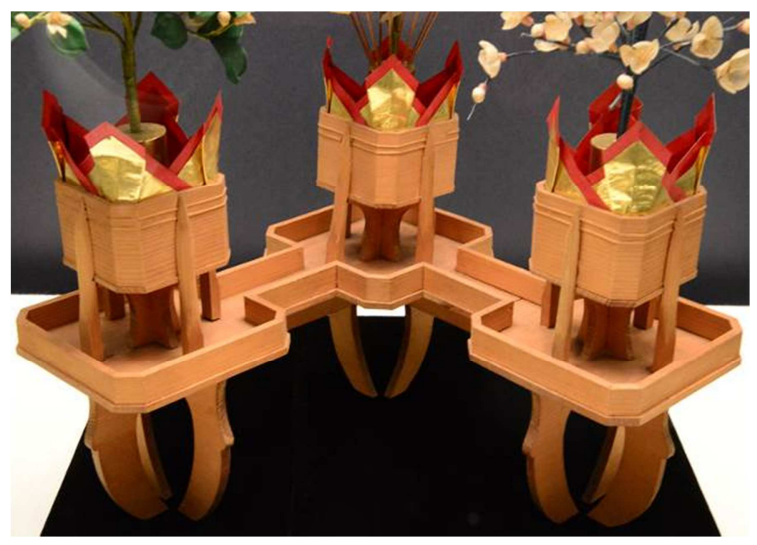

Figure 19. Flower arranging device that ancestors of CHISO's head family had made, for dedicating to god of Kasuga shrine in Nara. (Same model nowadays.) The Museum of Kyoto.

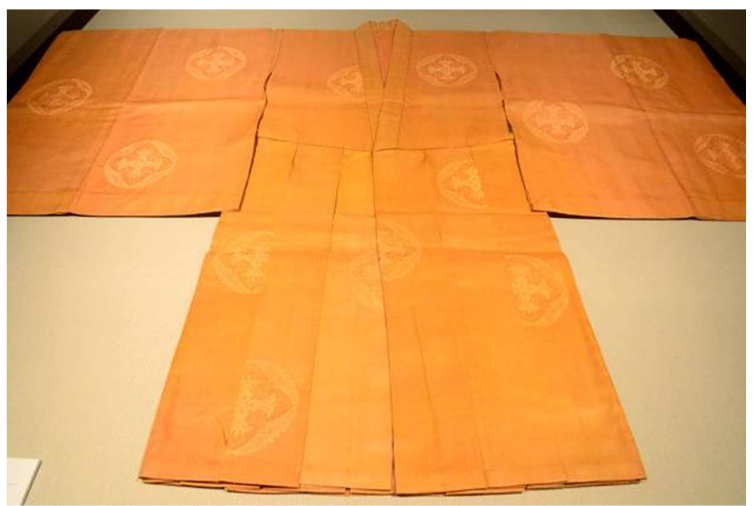

Figure 20. Clerical garments manufactured by CHISO in 19th century. The Museum of Kyoto. IYEMON SALON KYOTO.

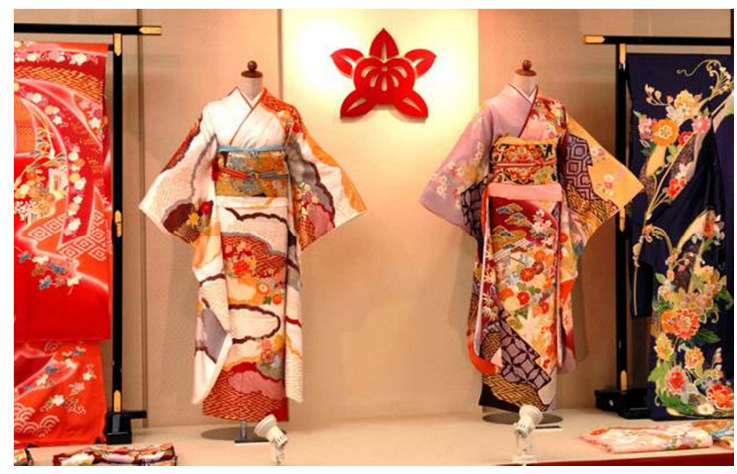

Figure 21. Examples of Yuzen kimono sold by CHISO.

Table 6. CHISO's several crises in the history.

\begin{tabular}{|c|c|c|}
\hline Year/Period & Crises & CHISO's Handling \\
\hline $\begin{array}{l}1555 / \\
\text { Muromachi }\end{array}$ & $\begin{array}{l}\text { It was the age of provincial wars. Shrines and temples were military } \\
\text { target for destruction. Shrine carpenters went out of business. }\end{array}$ & $\begin{array}{l}\text { Change their career from the shrine carpenter to making clerical } \\
\text { garments. }\end{array}$ \\
\hline 1683/ Edo & Sumptuary legislation prohibiting gold brocade. & Inventing Yuzen. \\
\hline 1868/ Meiji & Europeanizing policy by the Meiji new government. & $\begin{array}{l}\text { Creating the mold-dye Yuzen for mass production. } \\
\text { Using famous Japanese-style painters as designers. }\end{array}$ \\
\hline 1940/ Showa & $\begin{array}{l}\text { World War II. } \\
\text { Sumptuary law in the war time. } \\
\text { "Luxury is enemy!" campaign in the war. }\end{array}$ & $\begin{array}{l}\text { Retrieving the government's permission for continuation of } \\
\text { production and distribution in during the sumptuary law. }\end{array}$ \\
\hline 1990/ Heisei & $\begin{array}{l}\text { Collapse of the bubble economy that causing the long stagnation and } \\
\text { cutback of luxury Kimono market. }\end{array}$ & $\begin{array}{l}\text { Collaboration with the other industry sector and modern artists. } \\
\text { Expansion to the retailing for the first time. }\end{array}$ \\
\hline
\end{tabular}


The fourth crisis revolved around a war with China in 1937 and World War II with the United States in 1941. In 1938, the government began war-time economic control and promulgated the sumputuary legislation prohibiting the production of luxury goods, including the Yuzen kimono. Chiso managed to obtain permission from the government to continue production and distribution during the period of sumptuary law enforcement.

The fifth crisis was the collapse of the bubble economy in 1990 and a decade of stagnation and deflation that followed. Demand for luxury goods plummeted significantly during this time, and CHISO was focused to adapt. First, the company reduced personnel by dismissal or calling for voluntary retirement. Next, CHISO tried to form partnerships with other industry sectors and also modern artists such as Takashi Murakami. CHISO also expanded into retailing for the first time, but the company elected not to market its luxury line in order to ward off the cannibalization with from high-end department stores. CHISO named retailing store "SOHYA" in order to distinguish its consumer line from its luxury products.

The 460 year long history of CHISO shows many epiphanies for the study of management. The management of CHISO especially presents two things: the crisis management and also the affection management.

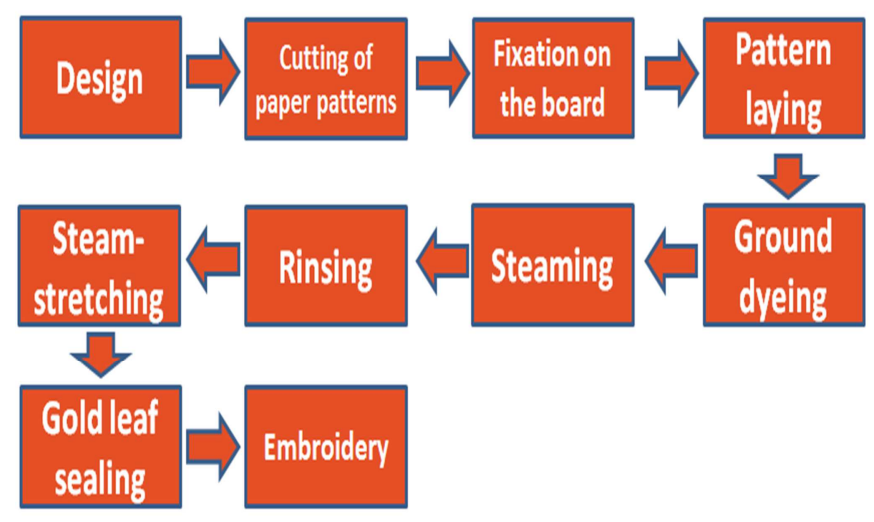

Figure 22. The manufacturing process of Yuzen kimonos with paper pattern.

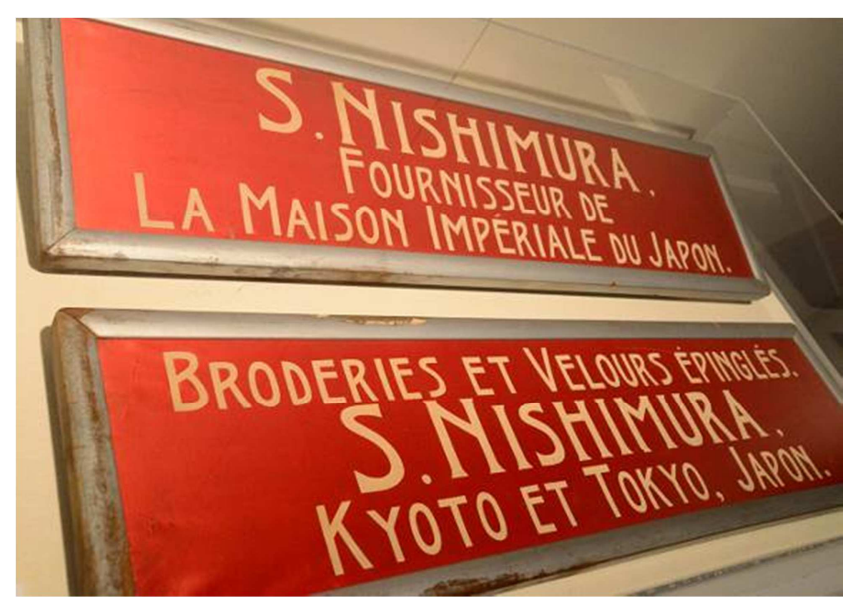

Figure 23. French trade sign of CHISO (NISHIMURA) in $19^{\text {th }}$ century. The Museum of Kyoto.
Both are inseparably linked each other. Because no company would survive without the affectiveness of consumers.

\section{Overcome Crises with Customer Experiences}

There is a phrase, "Huge crisis once in a century." This phrase was used in the time of the Great East Japan Earthquake in 2011. CHISO actually experienced several times of such huge crises. CHISO handled well each time of crises. CHISO used various method of response. Founder of CHISO used an entry into a new sector: by innovation of organization, in sixteenth century. CHISO responded to sumptuary law, by an innovation of inventing revolutionary method to manufacture Yuzen in seventeenth century. CHISO responded to the Europeanizing policy by Meiji government, by innovation of creating the pattern mold-dye method, for mass production to enlarge the Yuzen market, wide-spreading to the ordinary people who had been holding admiration for Yuzen. And CHISO exported the drawing arts to Europe. In the decade long economic depression after the collapse of bubble economy, CHISO has been trying collaboration with the other industry in order to get a new innovation. Such a long history of innovation and flexibility nurtured the unique culture of CHISO of its contradictory elements mixed: tradition and innovation.

Clayton Christensen said, "Innovative companies are almost always led by innovative leaders and we saw how innovative founders often imprinted their organizations with their behaviors." $\mathrm{He}$ also said, "DNA of innovative organizations mirrored the DNA of innovative individuals. In other words, innovative people systematically engage in questioning, observing, networking, and experimenting behaviors to spark new ideas." In the case of CHISO, the founder began the corporation with change his vocation in order to cope with the situation of war time. It is able to be called, 'organizational innovation.' Such a spirit of innovation is handed down to Nishimura family of CHISO generation to generation.

4Ps, SWOT, and VRIO analysis depicted the advantage or disadvantage and also the dilemma of CHISO.

Just like as the "Innovator's dilemma," told by Clayton Christensen, CHISO has been an innovator, and they also have such a dilemma. CHISO invented the revolutionary method of manufacturing Yuzen in Edo period, and also invented the mold-dye Yuzen method for mass production in Meiji era. However, such an efficient method for mass production also became very beneficial to new competitors making bargain sales. Such new bargain sellers were selling at the price less than one-tenth of CHISO's price.

In spite of such impassable difficulties, why CHISO could still survive? CHISO is nothing of kind, matches the discount policy of its competitors. CHISO has been managing to make its image as a brilliant luxury brand. In this point, CHISO 
could survive by using skillful command of experiential value.

\section{Conclusion}

According to Bernd H. Schmitt, traditional marketing is largely focused on functional features and benefits. Traditional marketers assume that customers in a variety of markets weigh functional features in terms of their importance, assess the presence of product features, and select the product with the highest overall utility. Everything that does not fit into this framework gets labeled at best as "image" or "brand" effect, without any conceptual understanding of what that means.

According to Philip Kotler, features are "characteristics that supplement the product's basic function." Because, customers are assumed to make choices based on features, product features are viewed as a key tool for differentiating a company's offerings from competitive offerings.

What is the feature of Yuzen kimono. It is the mystic beauty of traditional crafts products, of course. Although some of amateurs may not able to tell CHISO's Yuzen from discounters' Yuzen, aficionados definitely can tell those. Surprisingly, they can even tell which is made by CHISO, although there is no brand name on the surface of those kimonos. These aficionados or aficionadas must be called 'prosumers.' As the luxury kimono manufacturer, CHISO had been mainly targeted such prosumers. Features: characteristics that supplement the product's basic function might be same on both CHISO's Yuzen and the other kimono discounters' Yuzen. In order to analyze such a subtle difference in these products, customer experience or experiential value is essential and indispensable.

\section{References}

[1] H. Chesbrough (2003) Open Innovation, Harvard Business School Publishing, Cambridge, MA.

[2] H. Chesbrough (2006) Open Business Model, Harvard Business School Publishing, Cambridge, MA.

[3] C. M. Christensen (1997) The Innovator's Dilemma, Harvard Business School Publishing, Cambridge, MA.

[4] C. M. Christensen (2003) The Innovator's Solution, Harvard Business School Publishing, Cambridge, MA.

[5] C. M. Christensen (2004) Seeing What's Next, Harvard Business School Publishing, Cambridge, MA.

[6] C. M. Christensen (2011) The Innovator's DNA, Harvard Business School Publishing, Cambridge, MA.

[7] D. J. Collis and C. A. Montgomery (1998) Corporate Strategy: A Resource-Based Approach, McGraw-Hill, New York, NY.

[8] M. Ishikawa and S. Nagasawa (2010) Yonhyaku-goju nen-no Brand Innovation [Brand Innovation of 450 years], Doyukan, Tokyo (in Japanese).

[9] G. A. Moore (2005) Dealing with Darwin, Portfolio, New York, NY.

[10] G. A. Moore (2006) Crossing the Chasm, Harper Business, New York, NY.

[11] W. D. Perreault, and E. J. McCarthy (1999) Basic Marketing: A Global-managerial Approach, McGraw-Hill, New York, NY.

[12] M. E. Porter (1979) On Competition, Harvard Business School Publishing, Cambridge, MA.

[13] M. E. Porter (1996) "What is Strategy?", Harvard Business Review, Nov.-Dec.

[14] Schmitt, B. H. (1999), Experiential Marketing: How to Get Customers to Sense, Feel, Think, Act, and Relate to Your Company and Brands, Free Press, Detroit. 